\section{OTOLOGY AND FOLKLORE}

$I^{\mathrm{N}}$

$\mathrm{N}$ a recent paper (J. Laryng. and Otol., 57, 311 ; 1942) on this subject, Dr. J. D. Rolleston stated that though Toynbee is generally acknowledged to be the founder of modern otology, the first recognition of ear disease can be traced back to the Ebers papyrus, which contains a monograph on "ears hard of hearing" and on "ears from which there was a putrid discharge". Although there is an enormous amount of literature connected with the history of otology, the only comprehensive study of the folklore of this speciality is that furnished by Hovorka and Kronfeld in their treatise on comparative folkmedicine.

Among the numerous popular beliefs and superstitions connected with the ear, the most interesting to folklorists and students of the history of religions is the idea of the ear serving as the female organ of generation, particularly in the conception of Jesus, which was supposed to be effected by introduction into the Virgin Mary's ear of the breath of the Holy Ghost. Belief in this unusual function of the ear, which was often illustrated by medieval artists, is not peculiar to Christian mythology; it is also found in Mongolian, Persian and Indian legends. A belief in a relation between the size or shape of the external ear and the character of the individual was widespread, small ears being a sign of mental power, large ears indicating dullness, and pointed ears a bad character.

The belief that tingling of the ear is a sign that others are speaking of you dates back to the time of Pliny, who stated that this was then a universally accepted notion.

A belief once prevalent in the north-east of Scotland was that deaf mutes possessed the faculty of looking into the future and discovering what was hidden to others.

In accordance with the rule that prophylaxis is much rarer in folklore medicine than curative measures, there are comparatively few instances of preventive measures employed against ear disease, and, such as they are, consist mainly of amulets. Therapeutic treatment, on the other hand, was abundant, and can be elassified under the headings of animal remedies, including coprotherapy, plant remedies, mineral remedies, hydrotherapy, invocation of patron saints and miscellaneous remedies.

\section{FORTHCOMING EVENTS}

(Meetings marked with an asterisk are open to the public)

Monday, October 26

Royal Institute of Publio Health and Hygiene (at 28 Portland Place, London, W.1), at 3 p.m. - Prof. J. C. Drummond : "The Background to the Study of Nutrition in War-Time" (Harben Lectures, 1).* ROYAL GEOGRAPHICAL Socrety (at Kensington Gore, London,
s.W.7), at 8 p.m.-Miss Mildred Cable: "A. New Era in the Gobi".

\section{Tuesday, October 27}

Royal Institute of Public Health and Hygiene (at 28 Portland Place, London, W.1), at 3 p.m.- Prof. J. C. Drummond : "Defleiency
(onditions to be guarded against in War-Time" (Harben Lectures, 2)."

\section{Wednesday, October 28}

Royal Institute of PUblic Health and Hygiene (at 28 Portland Place, London, W.1), at 3 p.m.-Prof. J. C. Drummond: "Measures taken to Maintain a Good Nutritional Condition of the People in WarTime" (Harben Lectures, 3).*

Thursday, October 29

BRITISH SOCIETY FoR INTERNaTional BIBLIOgRAPHy (at the Science Museum, Exhibition Road, South Kensington, London, S.W.7), at
2.15 p.m.-Mr. T. Besterman : "A Projected Bibliography of Diction2.15 p.m. Mr. T. Besterman: "A Projected Bibliography of Dict
Friday, October 30

Iister Institute of Preventive Medione (at the London School of Hygiene and Tropical Medicine, Keppel Street, London, W.C.1), at 3 p.m.-Prof. P. A. Buxton:; "Bacot's Work on the Louse and some of its Recent Developments"; (First Bacot Memorial Lecture).* FREE GERMAN INSTITUTE OF SCIENCE AND LaRning (at 16 BuckFREE GERMAN INSTITUTE OF SCIENCE AND LRARNING (at 16 Buck-
land Crescent, Hampstead, London, N.W.3), at, 8 p.m.-Dr. K. Mendelssohn:" "Temperatures near Absolute Zero"." p.m.-Dr. K.

\section{Saturday, October 31}

Institute of Physics (ELECTRONICS Group AND MIDLAND BRANCH) (at the College of Technology, Rugby), at 2.45 p.m.-Dr. D. Gabor : "Electron Optics".

\section{APPOINTMENTS VACANT}

Applications are invited for the following appointments on or before the dates mentioned:

Assistant Master to take Mathematics, Engineering DrawING AND ENGINemring Sctence-The Principal, Enfleld Technical ING, AND ENGINEERING ScTENCE-The Principal, Enf
College, Queensway, Enfleld, Middlesex (October 30).

Lecturer in Engrnemerna-The Principal and Clerk to the Governing Body, Wigan and District Mining and Technical College, Wigan (October 31 ).

Graduate or Non-graduate Teacher of Enginegring SubJECTS, INCLUDING WORKSHOP INSTRUCTION, at the Grimsby Technical College-The Director of Education, Education Offices, Eleanor Street. Grimsby (October 31).

Lecturer in Meohanical or Electrioal Engingering-The Registrar, Loughborough College, Loughborough, Leics. (October 31 ). Lecturer in Chemistry at the Technical College, Cardiff--The Director of Education, City Hall, Cardiff (November 1).

Teacher in the Engineering Department-The Principal, Municipal Technical College, Halifax (November 2),

TEACHER TO GIVE INSTRUCTION IN THE ENGINEERING WORKSHOPS -The Principal, Municipal Technical College, Halifax (November 2).

Chinf Assistant EngineER-The General Manager, Port of Bristol Authority, Docks office, Queen Square, Bristol 1 (endorsed 'Chief

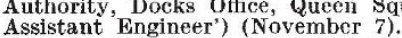

Two Instructors for Day Classeg for Training of Marink ENGINEERS, at the Stow College, School of Engineering-The Director of Education, 129 Bath Street, Glasgow, C.2 (November 20).

LECTURER FOR THE ENGINEERING DAPARTMENT of the Stockport College for Further Education-The Director of Education, Education Offices, Town Hall, Stockport.

LeCTURESHIP IN THE DEPARTMENT OF MEChaNiCAL ENGINEERING -The Principal, Central Technical College, Suffolk Street, Birmingham 1 .

\section{REPORTS and other PUBLICATIONS}

(not included in the monthly Books Supplement) Great Britain and Ireland

Economic Proceedings of the Royal Dublin Society. Vol. 3, No. 12. Seaweed (Laminaria) as Stock Food By Prof. E. J. Sheehy and $J$. Brophy and Prof. T. Dillon and P. O'Muineachain. Pp. 150-161. (Dublin: Hodges, Figgis and Co., Ltd.; London: Williams and Norgate, Ltd.) 18.
[249 Scientific Proceedings of the Royal Dublin Society. Vol. 23 (N.S.), No. 3: Atmospheric Pollution in Dublin during the Year 1941. By A. G. G. Leonard, Bridget P. MeVerry and D. Crowley. Pp. 10-17. (Dublin: Hodges, Figgis and Co., Ltd.; London: Williams and Norgate, Ltd.) 18.
[249

British Rubber Producers' Research Association. Publication No. 23: The Phosphatides of Hevea brasiliensis. By G. R. Tristram. Pp. 8. (London: British Rubber Producers' Research Association.) [259 Edinburgh and East of Scotland College of Agriculture. Calendar
for 1942-1943. Pp. 64. (Edinburgh: Edinburgh and East of Scotland for 1942-1943. Pp. 64. (Edinburgh : Edinburgh and East of Bcotland
College of Agriculture.) Proceedings of the Royal Society of Edinburgh, Section B : Biology. Vol. 61, Part 3, No. 23: Types of Development of Polytene Chromosomes. By Dr. A. M. Melland. Pp. 316-327+1 plate. (Edinburgh and London: Oliver and Boyd.) $1 s .3 d$.

\section{Other Countries}

Report of His Majesty's Astronomer at the Cape of Good Hope to the Secretary of the Admiralty for the year 1941. Pp. 7. (Cape of Good Hope: Royal Observatory.)

Indian Central Cotton Committee: Technological Laboratory. Technological Research on Cotton in India: being an Account of the Work done at the Indian Central Cotton Committee Technological Laboratory, 1924-1941. By Dr. Nazir Ahmad. Pp. xi +182+12 plates. Bombay : Indian Central Cotton Committee.) 2.8 rupees. Indian Forest Records (New Series). Entomology, Vol, 7, No. 1 : On the Biology of the Parasites of the Shisham Defoliators in the
Punjab Plantations. By R. N. Mathur, with a Note by C. F. C. Beeson. Pp. lii +65 . (Delhi: Manager of Publications.) 2 rupees;
[710. Smithsonian Miscellaneous Collections. Vol. 101, No. 18: A New Species of Sand Bug, Blepharipoda doelloi, from Argentina. By Waldo L. Schmitt. (Publication 3687.) Pp. $10+1$ plate. (Washington, D.C.:
Smithsonian Institution.) 